\title{
The Indian Women Writers and their Contributions to Indian Literature
}

\author{
Krishnaveni KP
}

Department of English (PG) Kristu Jayanti College, Autonomous, Hennur Main Rd., K Narayanpura, Kothanur (P0), Bengaluru, Karnataka.

\begin{abstract}
The Indian women writers are the one who mainly talks about the male ego and female desire for freedom. Through their writings women writer tries to oppose the male dominance over them. Indian women writers depict the injustices, the anguish and the despair they received in a male dominated society. Many of the writings can be considered as a mutiny against the restraints which the society thrust upon women. In this man-centered world they are trying to bring out the feminine identity through their works.

Indian women writers never attempted to adopt any masculine roles to achieve themselves as equal as men, but through their writings they came across all the barrier of class, gender and space boundaries. They try to project masculinity and femininity as equal categories. Though through their works the Indian women writers tries to project women's responses to gender questions. However, they tried to depict the fact that writings of women need not be differentiated by language or location.
\end{abstract}

KEYWORDS: Male dominated society, masculinity, feminine sensibility, identity.

\section{INTRODUCTION}

Women are intrinsically artistic in nature. India is a patriarchal society where Man occupied a very prominent position as compared to women. In such a situation to do something different and intellectual is a challenge .The contributions of Indian Women writers are appreciated in all literary categories. Women writers try to express the discrimination, dissatisfaction and agony through their works. Each writings of these women writers go beyond all those gender theories and react against it. Their writing come out that urge for freedom and to break all those oppressive forces. They have depicted the life woman who is trapped between their own aspirations and the constricting forces of patriarchy.

The Indian women writers like Shashi Desh Pande, Nayanthara Seghal, Arundathi Roy, and Kamala Markandaya expressed the role and position of woman through their writings in English. They have expressed the real oppression and fight of women to achieve gender equality.

Shashi DeshPande is the one novelist who is labelled as feminist novelist who dealt with the problems faced by women in our patriarchal society. Through her works she gave a detailed picture of women's issues, emotional and spiritual crisis they encounter in this male dominated society.
The characters in her novel is having a quest for freedom and all they want is to come out of these oppressive bond and to reconstruct all those norms and patterns of womanhood. She talks about the women's struggle to secure self-identity and self-respect. Shashi Desh Pande's novel That Long Silence (1988) tells the story of Jaya, an Indian upper- middle class house wife who retained her silence in Bombay throughout her life. Here she talks about the institution of marriage and its power to destroy the freedom of women. Through this works she tries to reveal the fact that women bare the levels of oppression not only within the male centred society but also within the institution of the family.

In The Binding Vine (1993), through the narrator-protagonist Urmila highlights the despair of two women, one is Mira, who is a victim of marital rape and the other is Kalpana, who is a brutally raped outside marriage. This is a novel that takes up the issue of rape both within and outside marriage.

In another novel Roots \& Shadows (1983), there is another rebellious woman who refuses to accept traditional family life and escapes to the city. In almost all novels of Deshpande dealt with a crisis in the heroines' life. This novel depicts the pain and suffocation of the protagonist Indu in the male dominated society. She tries to escape from an adulterous relationship with Narendra to find her real self. 
Nayanthara Seghal is also another writer who portrayed the image of women who suffered due to the sexiest bias in the patriarchal society. Through her writings she envisions a world which is based on equality and the virtues of women to be equally valued as that of men. Her Novel presents the image of Indian Womanhood. Women are the principle characters in her novels. She comments on the freedom of females. Her feminist voice is strong and louder which is the result of her unhappy married life. Saghal's woman from A Time to be Happy (1957) to Mistaken Identity (1988) is all about the journey of women's struggle towards self-discovery. Motherhood is another category which has been critiqued and reviewed. Saghal's portrayal of motherhood is framed by a larger discourse. Her focus is more on women and value structures.

In The God of small things (1997), Arundathi Roy thinks beyond all the stereotypical characters of Women. The protagonist, Ammu - a mother of a son and a daughter - a divorcee is a rebel, who embarks on a journey with a man she loved - an untouchable thereby defies the planet altogether She seems to assert that women is an individual soul who is having a voice of their own. She has the ability to shape her own destiny and is as capable as men. They are having their own identity and individuality. Roy attacks the age old traditional norms and tried to exert feminism in her works. She focuses more on the social injustices against women and she had changed all the perception of women's identity in Indian society. Arundathi Roy succeeded in bringing down the existing social order. Being an activist, she is constantly writing about social problems and the plight of woman.

Kamala Markandaya's Nectar in a Sieve (1954), depicts women's issues and problems very deeply. She explores and interprets the emotional reactions and spiritual responses of the women and their predicament with sympathetic understanding and shows that women are not lesser than human; rather they are sometimes more dignified than men due to their greater human virtues, qualities and creativity. They suffer heroically, though they are strong willed. A number of women sublimate their desires in religious faith. She describes that an Indian woman has to face between tradition and modernity. Kamala Markandaya's main focus, which she effectively presents, is the predicament of women in these situations. Her Rukmani, no doubt, may be a triumph of the spirit of tradition.
In a male dominated society, it had been a serious effort for the women writers to show what society called as the mechanics of patriarchy. The work of Indian women writers has been undervalued due to these patriarchal assumptions. To fight against the cultural a mind set in men and women, one of the first things that these women writers did was to form their writings more eclectic. Another critical issue that was handled by these women writers was the difficulty of 'Style in language'. It was Jane Austin who devised a way for writing that was perfectly natural, elegant and proper for the utilization of women writers. Women could now write in clauses that were linked in loose sequences, instead of balanced and patterned as used by male writers.

The majority of writings by Indian women writers depict the sufferings of the frustrated homemakers and questions of the prominent old patriarchal domination. Anita Desai, Shashi Deshpande, Arundathi Roy represent their heroines defying patriarchal notions and they posses their own individuality and identity. They want to lead their life independently. They are bold, strong and independent human beings. They want live freely and fully. By their novels these women writer try to tackle the systems that oppress and subjugate women.

\section{CONCLUSION}

This paper gave a view of how Indian women writers bring out the oppression and suppression of the women in this patriarchal society. Each works is an open window to the feminine world to reconstruct the world of suppressed emotions of women. From this it is evident that women began to utilize the power of the pen. Women's writing of all kinds is considered to be valuable as that of men. It has come the age in terms of quality and variety. So the credit goes to women novelists whose contribution counts a lot in the writing and publishing of novel. They try varied themes, techniques or styles, raise issues of caste, class, gender, identity and individuality. So the contribution of Indian women writers to Indian novel in English is tremendous.

\section{REFERENCES}

1. Indian Women Novelists. Set III, Vol.4. New Delhi. Prestige books. 1995. Print.

2. Deshpande, Shashi. That Long Silence, New Delhi: Penguin India, 1989. Print.

3. Indian English Literature 1980-2000: A Critical Survey. Delhi: Pencraft International.2001. Print. 
4. Roy, Arundhati. The God of Small Things. New Delhi: IndiaInk. 1997. Print.

5. Sahgal, Nayantara. Plans for Departure 1989. Print.

6. Ravi, P.S. Modern Indian Fiction: History, Politics and Individual in the Novels of salman Rushdie, Amitav Ghosh and Upamanyu Chatterjee New Delhi: Prestige Books, 2003. Print.
7. Naik, M.K. A History of Indian English Literature. New Delhi: Sahitya Akademi. 1982. Print.

8. Betty, Frieday. The Feminine Mystique. New York. Dell, 1963. Print.

9. Recent Indian Fiction edited by R.S.Pathak, Prestige books: New Delhi. 1994. Print.

Citation: Krishnaveni KP, "The Indian Women Writers and their Contributions to Indian Literature". American Research Journal of English and Literature, Volume 7, Issue No. 1, 2021, pp. 1-3.

Copyright (C) 2021 Krishnaveni KP, This is an open access article distributed under the Creative Commons Attribution License, which permits unrestricted use, distribution, and reproduction in any medium, provided the original work is properly cited. 